\title{
SANKSI TINDAK PIDANA PENCANTUMAN KLAUSULA BAKU PADA KARCIS PARKIR KENDARAAN BERMOTOR
}

\author{
Moch. Choirul Rizal \\ Lembaga Bantuan Hukum Surabaya Jl. Kidal No.6 Surabaya | mcrizal90@gmail.com
}

\begin{abstract}
This article discusses about a criminal sanction of the standard clauses in a motor vehicle parking ticket for parking service manager according to article 18 paragraph (I) jo. article 62 paragraph ( I) of Law No. 8 year 1999 about consumer's protection. Standard clause is an agreement where the procedure of making it is unilateral. A standard clause listed on the ticket motorists has violated the provision of article 18 paragraph ( I) letter a, namely "the businesses doers, in offering goods and/or services that are held for trading, are prohibited from making or including a standard clauses in each document and/or agreement if they had declare the transfer of responsibility of entrepreneurs". The inclusion of a standard clause as mentioned in the above provisions can be categorized as a criminal offense. The criminal penalty of such act is imprisonment of a maximum 5 (five) years or a criminal sanction of a maximum Rp. 2,000,000,000.00 (two billions rupiah) as stipulated in article 62 paragraph (I) UUPK. In Islam, these are included a criminal act and they have not stipulated in the text yet. So that, it becomes the authority of ulil 'amrito determine the punishment.
\end{abstract}

Keywords: Sanctions, criminal act, standard clause, motor vehicle.

Abstrak: Artikel ini membahas tentang sanksi tindak pidana pencantuman klausula baku pada karcis parkir kendaraan bermotor terhadap pengelola jasa parkir menurut Pasal 18 ayat (I) jo. Pasal 62 ayat (I) Undang-Undang Nomor 8 Tahun 1999 Tentang Perlindungan Konsumen (UUPK). Klausula baku merupakan perjanjian yang prosedur pembuatannya bersifat sepihak. Klausula baku yang tercantum pada karcis kendaraan bermotor telah melanggar ketentuan dalam Pasal 18 ayat (I) huruf a, yakni "pelaku usaha dalam menawarkan barang dan/atau jasa yang ditujukan untuk diperdagangkan dilarang membuat atau mencantumkan klausula baku 
pada setiap dokumen dan/atau perjanjian apabila menyatakan pengalihan tanggung jawab pelaku usaha." Pencantuman klausula baku sebagaimana ketentuan di atas dapat dikategorikan sebagai tindak pidana. Sanksi bila pelaku usaha tetap melakukan tindak pidana tersebut adalah dengan pidana penjara paling lama 5 (lima) tahun atau pidana denda paling banyak Rp.. 2.000.000.000,00 (dua miliar rupiah) sebagaimana ketentuan pada Pasal 62 ayat (I) UUPK. Dalam Islam, sanksi tersebut termasuk dalam sanksi jarimah ta'zir, tindak pidana yang dimaksud belum diatur di dalam nas, sehingga menjadi kewenangan ulil 'amri untuk menghukuminya.

Kata Kunci: Sanksi, tindak pidana, klausula baku, kendaraan bermotor.

\section{Pendahuluan}

Sebagai kota metropolitan, Surabaya menjadi pusat kegiatan perekonomian di daerah Jawa Timur dan sekitarnya. Salah satu buktinya adalah terdapat puluhan pusat perbelanjaan modern (mall) ternama di Surabaya, diantaranya: Ciputra World, Tunjungan Plaza, Pakuwon Trade Center, Mall Galaxy, Golden City Mall, Bubutan Junction (BG Junction), Royal Plaza, City of Tomorrow (CiTo), Surabaya Town Square (Sutos), Hi Tech Mall, Grand City Mall, Maspion Square, MEX Building, Pasar Atum Mall, ITC Surabaya, Plaza Marina, dan Plasa Surabaya yang oleh masyarakat Surabaya lebih dikenal dengan Delta Plaza. ${ }^{1}$

Berdirinya mall di Surabaya menarik minat konsumen untuk berkunjung sekaligus berbelanja berbagai kebutuhan. Pada umumnya, konsumen yang mengunjungi mall banyak memanfaatkan kendaraan pribadi, baik sepeda motor maupun mobil sebagai sarana transportasi untuk menjangkau tempat tujuan. Sehingga, setiap mall yang berdiri kokoh selalu tersedia lahan parkir bagi kendaraan yang digunakan oleh konsumen.

Penyediaan lahan parkir merupakan wujud perhatian pelaku usaha (pendiri mall) untuk langkah pengaman bagi kendaraan

\footnotetext{
Wikipedia, "Daftar Pusat Perbelanjaan di Surabaya", dalam http://id.wikipedia.org/wiki/Daftar_Pusat_Perbelanjaan_di_Surabaya, diakses pada II Oktober 2012.
} 
konsumen yang tengah berkunjung. Adapun salah satu bentuknya adalah penitipan sepeda motor dan mobil. Konsumen dikatakan menitipkan kendaraannya yakni saat kendaraan yang dimaksud memanfaatkan lahan parkir yang disediakan pelaku usaha. Dan pada saat itu juga, konsumen mendapatkan tanda bukti penitipan berbentuk semacam lembaran, yang umumnya disebut dengan karcis.

Niat baik pelaku usaha dalam mengelola jasa parkir bagi konsumen tidak selamanya terealisasikan. Tak putus dirundung malang, sepertinya ungkapan ini tepat bagi konsumen jasa peRp.arkiran. Betapa tidak, selain harus bersiap merogoh kocek lebih dalam akibat kebijakan tarif parkir yang berbeda-beda, keamanan konsumen parkir juga mulai tergerus. Lebih malang lagi, karena setiap mengurus kehilangan barang ditempat parkir, konsumen harus beradu mulut dengan operator. Bahkan, acapkali kehilangan barang atau kendaraan di tempat parkir berakhir tanpa mendapatkan ganti sepadan. ${ }^{2}$

Selama ini, pengelola parkir terkesan enggan mengganti kehilangan barang atau kendaraan di area parkir. Artinya, konsumen harus menanggung sendiri resiko terjadinya kerusakan dan kehilangan atas kendaraan serta barang-barang didalamnya. ${ }^{3}$ Pengelola jasa parkir selalu beralasan bahwa itu sesuai dengan perjanjian/klausula yang mengikat antara pengelola dan konsumen yang telah tertuang di karcis parkir, yakni: "Pengelola parkir tidak bertanggungjawab terhadap kehilangan barang dan/atau kendaraan", dan dengan berbagai macam kalimat yang menyerupainya.

Pencantuman perjanjian yang telah tersebut di atas merupakan salah satu bentuk dari klausula baku. Artinya ialah "setiap aturan atau ketentuan dan syarat-syarat yang telah dipersiapkan dan ditetapkan terlebih dahulu secara sepihak oleh

2 Karunia Asih Rahayu, "Melawan Klausula Baku Tiket Parkir", dalam http://www.ylki.or.id/melawan-klausula-baku-tiket-parkir.html, diakses pada II Oktober 2012. ${ }^{3}$ Ibid. 
pelaku usaha yang dituangkan dalam suatu dokumen dan/atau perjanjian yang mengikat dan wajib dipenuhi oleh konsumen". ${ }^{4}$ Setiap klausula baku yang telah dibuat oleh pelaku usaha -dalam hal ini adalah pengelola jasa parkir- merupakan perbuatan yang dilarang, sebagaimana pada Pasal 18 UUPK.

Larangan dan persyaratan tentang pencantuman klausula baku merupakan salah satu wujud keseimbangan dalam hal kedudukan antara konsumen dan pelaku usaha berdasarkan prinsip kebebasan berkontrak. Kemudian, ketentuan ini merupakan upaya untuk mencegah munculnya berbagai tindakan yang merugikan konsumen karena faktor ketidaktahuan, kedudukan yang tidak seimbang, dan sebagainya yang mungkin dapat dimanfaatkan oleh pelaku usaha untuk memperoleh keuntungan dengan jalan melanggar hukum. ${ }^{5}$

Pencantuman klausula baku pada karcis parkir kendaraan bermotor di mall di Surabaya masih tumbuh subur. Fenomena ini lantas menjadi lazim dan menjadi hal yang tampak umum. Padahal, menurut Pasal 62 ayat (1) UUPK, pencantuman klausula baku termasuk perbuatan yang dapat diancam dengan pidana penjara paling lama 5 (lima) tahun atau pidana denda paling banyak Rp.. 2.000.000.000,00 (dua miliar rupiah). Bahkan, hakim juga dapat menjatuhkan hukuman tambahan berupa pencabutan izin usaha. ${ }^{6}$

Meski UUPK menyatakan klausula baku terlarang batal demi hukum dan mewajibkan pengusaha pencantum untuk mencabutnya, ketentuan itu bak macan kertas. Penyidik Kementrian Perdagangan (Kemendag) belum pernah mengambil langkah represif bagi pelanggar. Polisi juga tidak terlihat sadar akan keberadaan ketentuan yang dilarang tersebut. Dengan kata lain, Pemerintah masih lemah dalam hal penindakan terkait

\footnotetext{
${ }^{4}$ Undang-Undang Nomor 8 Tahun 1999 tentang Perlindungan Konsumen, Pasal I angka I0.

${ }^{5}$ Janus Sidabalok, Hukum Perlindungan Konsumen di Indonesia, (Bandung: Citra Aditya Bakti, 2010), 27.

${ }^{6}$ Undang-Undang Nomor 8 Tahun 1999 Tentang Perlindungan Konsumen, Pasal 62 ayat (I) jo. Pasal 62 huruff.
} 
pelanggaran UUPK, karena baru sampai pemahaman akan isi UUPK. ${ }^{7}$

Secara normatif, setiap pelanggaran yang dilakukan produsen, maka kepadanya dikenakan sanksi-sanksi hukum, baik sanksi administratif maupun sanksi pidana sebagaimana ketentuan di atas. Perbuatan yang bertentangan dengan tujuan untuk menciptakan iklim usaha yang sehat, seperti pencantuman klausula baku pada karcis kendaraan bermotor di mall di Surabaya dapat dikategorikan sebagai perbuatan kejahatan. ${ }^{8}$

Istilah kejahatan memiliki makna perbuatan-perbuatan yang meskipun tidak ditentukan undang-undang sebagai perbuatan pidana, telah dirasakan sebagai perbuatan yang bertentangan dengan tata hukum. ${ }^{9}$ Dalam ranah hukum pidana ekonomi, dapat dikatakan pula bahwa pada umumnya kejahatan itu dilakukan dengan sengaja. ${ }^{10}$

Hukum pidana Indonesia memandang, bahwa pencantuman klausula baku merupakan perbuatan yang dapat dipidana karena telah teRp.enuhinya unsur-unsur perbuatan pidana. Pertama, unsur subjektif, yakni unsur yang berasal dari dalam diri pelaku yang meliputi perbuatan yang disengaja (dolus) atau karena kelalaian (culpa). Kedua, unsur objektif, yakni unsur yang berasal dari luar diri perilaku yang terdiri atas perbuatan manusia, akibat perbuatan manusia, keadaan-keadaan, adanya sifat melawan hukum, dan adanya sifat dapat dihukum..$^{11}$

Sanksi merupakan salah satu alat untuk mengembalikan keadaan pada keadaan semula manakala terjadi pelanggaran sekaligus sebagai alat preventif bagi pengusaha lainnya sehingga tidak terulang lagi perbuatan yang sama. ${ }^{12}$ Selain itu, adanya

7 Hukum Online, "Penindakan Pencantum Klausula Baku Terlarang Masih Minim," dalam http://www.hukumonline.com/berita/baca/hol I 7990/penindakan-pencantum-klausula-bakuterlarang-masih-minim, diakses II Oktober 2012.

${ }^{8}$ Janus Sidabalok, Hukum Perlindungan Konsumen di Indonesia, 94.

9 Moeljatno, Asas-Asas Hukum Pidana, (Jakarta: Rineka Cipta, 2009), 71.

${ }^{10}$ Andi Hamzah, Hukum Pidana Ekonomi, (Jakarta: Erlangga, 1996), 37.

"' Leden MaRp.aung, Asas-Teori-Praktik Hukum Pidana, (Jakarta: Sinar Grafika, 2008), 9- 10.

12 Janus Sidabalok, Hukum Perlindungan Konsumen di Indonesia, 94. 
sanksi dalam UUPK tersebut bermaksud untuk mengarahkan pelaku usaha untuk beRp.erilaku taat hukum dalam rangka mensukseskan pembangunan ekonomi nasional.

Berdasarkan uraian di atas, permasalahan yang timbul adalah belum mampunya UUPK -khususnya Pasal 62 ayat (1) tentang pemidanaan- untuk menjerat para pelaku usaha jasa pengelola parkir yang tetap mencantumkan klausula baku pada karcis kendaraan bermotor. Oleh karena itulah, dalam makalah ini membahas tentang sanksi tindak pidana pencantuman klausula baku pada karcis parkir kendaraan bermotor kepada pengelola jasa parkir.

\section{Pengertian Klausula Baku}

Hukum perlindungan konsumen dapat dikatakan sebagai hukum yang mengatur tentang pemberian perlindungan kepada konsumen dalam rangka pemenuhan kebutuhannya sebagai konsumen. Dengan demikian, hukum perlindungan konsumen mengatur hak dan kewajiban konsumen, hak dan kewajiban produsen, serta cara-cara mempertahankan hak dan menjalankan kewajiban itu. ${ }^{13}$ Diantara banyaknya pengaturan sebagaimana disebutkan di atas, Undang-Undang Nomor 8 Tahun 1999 Tentang Perlindungan Konsumen (UUPK) mewujudkan adanya pemenuhan hak konsumen dengan mengatur tentang larangan pencantuman klausula baku yang merugikan konsumen.

Klausula baku sebenarnya dikenal sejak zaman Yunani Kuno. Plato (423-347 SM) misalnya, pernah memaparkan praktik penjualan makanan yang harganya ditentukan secara sepihak oleh si penjual, tanpa memperhatikan perbedaan mutu makanan tersebut. ${ }^{14}$ Dalam perkembangannya, tentu saja penentuan secara sepihak oleh produsen atau penyalur produk (penjual), tidak lagi sekadar masalah harga, tetapi mencakup syarat-syarat yang lebih

\footnotetext{
13 Ibid., 45.

14 Shidarta, "Hukum Perlindungan Konsumen Indonesia", dalam Celina Tri Siwi K, Hukum Perlindungan Konsumen, (Jakarta: Sinar Grafika, 201 I), 138.
} 
detail. Selain itu, bidang-bidang yang diatur dengan perjanjian baku pun makin bertambah luas.

Di Indonesia, dalam praktiknya, klausula baku merupakan perjanjian yang prosedur pembuatannya bersifat sepihak. Hal ini berdasarkan Pasal 1 angka 10 UUPK yang mendefinisikan bahwa klausula baku adalah "setiap aturan atau ketentuan dan syaratsyarat yang telah dipersiapkan dan ditetapkan terlebih dahulu secara sepihak oleh pelaku usaha yang dituangkan dalam suatu dokumen dan/atau perjanjian yang mengikat dan wajib dipenuhi oleh konsumen." 15

Sutan Remi Sjahdeini mengartikan, bahwa perjanjian baku merupakan perjanjian yang hampir seluruh klausul-klausulnya dibakukan oleh pemakainya. Dengan demikian, pihak yang lain pada dasarnya tidak mempunyai peluang untuk merundingkan atau meminta perubahan. Sjahdeini menekankan, yang dibakukan itu bukan formulir perjanjian tersebut, melainkan klausulklausulnya.

Pembuat undang-undang ini menerima kenyataan bahwa pemberlakuan standar kontrak adalah suatu kebutuhan yang tidak bisa dihindari. Sebab, sebagaimana dikatakan oleh Sutan Remi Sjahdeini, perjanjian baku adalah suatu kenyataan yang memang lahir dari kebutuhan masyarakat. ${ }^{16}$ Namun demikian, dirasa perlu untuk mengaturnya sehingga tidak disalahgunakan dan/atau menimbulkan kerugian bagi pihak lain. Tinggal bagaimana pengawasan penggunaan standar kontrak itu sehingga tidak dijadikan sebagai alat untuk merugikan orang lain. ${ }^{17}$

Larangan dan persyaratan tentang pencantuman klausula baku merupakan salah satu wujud keseimbangan dalam hal kedudukan antara konsumen dan pelaku usaha berdasarkan prinsip kebebasan berkontrak. Kemudian, ketentuan ini merupakan upaya untuk mencegah munculnya berbagai tindakan

\footnotetext{
15 Undang-Undang Nomor 8 Tahun 1999 tentang Perlindungan Konsumen, Pasal I angka 10.

${ }^{16}$ Janus Sidabalok, Hukum Perlindungan Konsumen di Indonesia, 25.

17 Ibid.
} 
yang merugikan konsumen karena faktor ketidaktahuan, kedudukan yang tidak seimbang, dan sebagainya yang mungkin dapat dimanfaatkan oleh pelaku usaha untuk memperoleh keuntungan dengan jalan melanggar hukum. ${ }^{18}$

\section{Problematika Penggunaan Klausula Baku}

Konsultan perusahaan yang membuat klausula baku berusaha sedemikian rupa mengamankan dan melindungi kepentingan kliennya dari kemungkinan kerugian yang timbul jika perjanjian akhirnya tidak berjalan sebagaimana mestinya. Dengan demikian, isi perjanjian seperti ini umumnya cenderung menguntungkan pihak perusahaan. Karena itu pulalah, masalah klausula baku ini berkaitan erat dengan perlindungan konsumen dan menjadi salah satu ruang lingkup pembahasan perlindungan konsumen, yaitu melindungi konsumen dari kemungkinan diterapkannya syarat-syarat yang merugikan atau tidak adil di dalam perjanjian. ${ }^{19}$

Tentu saja fenomena di atas tidak selamanya berkonotasi negatif. Tujuan dibuatnya klausula baku adalah untuk memberikan kemudahan bagi para pihak yang bersangkutan. ${ }^{20}$ Selain itu, bentuk perjanjian tersebut sangat menguntungkan, jika dilihat dari berapa banyak waktu, tenaga, dan biaya yang dapat dihemat. $^{21}$

Praktik penggunaan klausula baku ini kemudian menimbulkan masalah hukum, bukan saja mengenai kejadian yang dicerminkan pada hak dan kewajiban para pihak, melainkan juga lebih mendasar lagi, yaitu mengenai keabsahan perjanjian itu sendiri. Ronny Bako beRp.endapat, bahwa "klausula baku

\footnotetext{
18 Ibid., 27.

19 Ibid., 14.

${ }_{20}$ Mariam Darus Badrulzaman, "Perlindungan Terhadap Konsumen Dilihat dari Perjanjian Baku (Standar)," dalam Celina Tri Siwi K, Hukum Perlindungan Konsumen, 139.

21 Sriwati, "Perlindungan Hukum Bagi Para Pihak dalam Perjanjian Baku," dalam Celina Tri Siwi K, Hukum Perlindungan Konsumen, 139.
} 
merupakan perjanjian paksa." 22 Bahkan, menurut Sluiter, standar kontrak ini bukanlah perjanjian, sebab di sini pengusaha berkedudukan sebagai pembuat undang-undang. ${ }^{23}$

Klausula baku mengandung ketidakseimbangan hak dan kewajiban para pihak sebagaimana yang diatur di dalam klausul tersebut. Artinya, pengusaha cenderung melindungi kepentingannya sedemikian rupa dengan menetapkan sejumlah hak sekaligus membatasi hak-hak pihak lawan (konsumen). Sebaliknya, pengusaha meminimalkan kewajiban-kewajiban sendiri dan mengatur sebanyak mungkin kewajiban pihak lawan. ${ }^{24}$

\section{Klausula Baku pada Karcis Kendaraan Bermotor}

Pencantuman klausula baku pada karcis parkir kendaraan bermotor di pusat perbelanjaan modern di Surabaya masih tumbuh subur. Fenomena ini lantas menjadi lazim dan menjadi hal yang tampak umum. Padahal, menurut Pasal 62 ayat (1) UUPK, pencantuman klausula baku termasuk perbuatan yang dapat diancam dengan pidana penjara paling lama 5 (lima) tahun atau pidana denda paling banyak Rp.. 2.000.000.000,00 (dua miliar rupiah). ${ }^{25}$

Pencantuman klausula baku pada karcis parkir kendaraan bermotor benar-benar masih terjadi, sebagaimana pada empat lembar karcis parkir kendaraan bermotor di pusat perbelanjaan modern di Surabaya yang terbagi dalam beberapa wilayah administrasi di Kota Surabaya, yang meliputi: (1) BG Junction (Surabaya Barat); (2) Jembatan Merah Plaza (Surabaya Utara); (3) Royal Plaza (Surabaya Selatan); dan (4) Hi-Tech Mall (Surabaya Timur). ${ }^{26}$

\footnotetext{
22 Ronny Bako, "Hubungan Bank dan Nasabah Terhadap Produk Tabungan dan Deposito," dalam Janus Sidabalok, Hukum Perlindungan Konsumen di Indonesia, 15.

${ }^{23} \mathrm{lbid} ., 15$.

${ }^{24} \mathrm{lbid}$.

${ }^{25}$ Undang-Undang Nomor 8 Tahun 1999 tentang Perlindungan Konsumen, Pasal 62 ayat (I).

${ }^{26}$ Wikipedia, "Kota Surabaya", dalam https://id.wikipedia.org/wiki/Kota_Surabaya, diakses pada 16 Mei 2013.
} 
Redaksi klausula baku yang tercantum pada karcis parkir kendaraan bermotor sebagaimana terdokumentasikan oleh penulis adalah sebagai berikut: (1) "Segala kerusakan ataupun kehilangan dari (bagian dari) kendaraan menjadi tanggung jawab dari pengendara." (BG Junction, Surabaya Pusat); (2) "Asuransi kendaraan dan barangbarang didalamnya serta semua risiko atas segala kerusakan dan kehilangan atas kendaraan yang diparkirkan dan barang-barang didalamnya merupakan kewajiban pemilik kendaraan itu sendiri." (Jembatan Merah Plaza, Surabaya Utara); (3) "Segala kerusakan pada kendaraan, kerusakan/kehilangan kelengkapan kendaraan maupun barang-barang didalamnya menjadi tanggung jawab pemilik kendaraan." (Royal Plaza, Surabaya Selatan); dan (4) "Manajemen Hi-Tech Mall menyatakan tidak bertanggung jawab atas segala bentuk kehilangan dan atau kerusakan kendaraan atau barang-barang lainnya. Kehilangan dan atau kerusakan kendaraan dan atau barang-barang lainnya menjadi tanggung jawab pemilik kendaraan." (Hi-Tech Mall, Surabaya Timur)..$^{27}$

Tindak Pidana Pencantuman Klausula Baku pada Karcis Kendaraan Bermotor Menurut Undang-Undang Nomor 8 Tahun 1999 tentang Perlindungan Konsumen

Hukum pidana Belanda memakai istilah strafbaarfeit, kadangkadang juga delict yang berasal dari bahasa Latin, delictum. Oleh karena KUHP Indonesia bersumber pada WVS Belanda, maka istilah aslinya pun sama, yaitu strafbaarfeit. Sekarang ini, semua undang-undang telah memakai istilah tindak pidana, seperti undang-undang tindak pidana ekonomi, undang-undang tindak pidana suap, dan seterusnya. ${ }^{28}$

Tindak pidana berarti suatu perbuatan yang pelakunya dapat dikenai hukuman pidana. ${ }^{29}$ Dapat dikatakan juga sebagai

\footnotetext{
${ }^{27}$ Hasil pengamatan di pusat perbelanjaan modern di Surabaya pada Oktober-Desember 2012.

${ }^{28}$ Andi Hamzah, Asas-Asas Hukum Pidana, (Jakarta: Rineka Cipta, 20 I 0), 94.

${ }^{29}$ Wirjono Prodjodikoro, Asas-Asas Hukum Pidana di Indonesia, (Bandung: PT Refika Aditama, 2009), 59.
} 
perbuatan yang oleh suatu aturan hukum dilarang dan diancam pidana. Larangan yang dimaksud ditujukan kepada perbuatan, yaitu suatu keadaan atau kejadian yang ditimbulkan oleh perbuatan orang. Sedangkan ancaman pidananya ditujukan kepada orang (subjek hukum) yang menimbulkan kejadian itu..$^{30}$

Hukum pidana Indonesia memandang, bahwa suatu perbuatan dapat dipidana jika telah teRp.enuhinya unsur-unsur perbuatan pidana yang dimaksud. Semua unsur tindak pidana yang akan dijelaskan di bawah ini merupakan satu kesatuan. Salah satu unsur saja tidak terbukti, bisa menyebabkan terdakwa dibebaskan Pengadilan. ${ }^{31}$

Unsur yang pertama adalah unsur subjektif, yakni unsur yang berasal dari dalam diri pelaku. Asas hukum pidana menyatakan, bahwa "tidak ada hukuman kalau tidak ada kesalahan." Unsur subjektif ini meliputi perbuatan yang disengaja (dolus) atau perbuatan karena kelalaian (culpa). ${ }^{32}$

Perbuatan yang disengaja (dolus) adalah suatu perbuatan kriminal yang dilakukan dengan sengaja bilamana pembuat delik menyadari perbuatannya dan ingin melakukannya, atau bilamana ia menyadari bahwa dengan perbuatannya atau pengabaiannya dapat menimbulkan konsekuensi (akibat) yang dilarang dan menyetujui terjadinya. ${ }^{33}$ Sedangkan perbuatan karena kelalaian (culpa) adalah suatu macam perbuatan yang dilakukan oleh pelaku tindak pidana yang kurang berhati-hati, sehingga akibat yang tidak disengaja terjadi. ${ }^{34}$

Unsur yang kedua adalah unsur objektif, yakni unsur yang berasal dari luar diri pelaku. Unsur ini terdiri dari atas perbuatan manusia, akibat perbuatan manusia, keadaan-keadaan, adanya sifat melawan hukum, dan adanya sifat dapat dihukum. ${ }^{35}$

\footnotetext{
${ }^{30}$ Moeljatno, Asas-Asas Hukum Pidana, 59.

${ }^{31}$ Leden MaRp.aung, Asas-Teori-Praktik Hukum Pidana, 10.

32 Ibid., 9- 10.

${ }^{33}$ A Zainal Abidin Farid, Hukum Pidana I, (Jakarta: Sinar Grafika, 1995), 273.

${ }^{34}$ Wirjono Prodjodikoro, Asas-Asas Hukum Pidana di Indonesia, 72.

${ }^{35}$ Leden MaRp.aung, Asas-Teori-Praktik Hukum Pidana, 9- 10.
} 
Perbuatan manusia dapat berupa: (a) act (commissions), yakni perbuatan aktif atau perbuatan positif; dan (b) omission, yakni perbuatan pasif atau perbuatan negatif yang wujudnya adalah perbuatan yang mendiamkan atau membiarkan. Di samping itu, akibat perbuatan manusia yang membahayakan atau merusak, bahkan menghilangkan kepentingan-kepentingan yang dipertahankan oleh hukum, juga menjadi bagian dari unsur objektif suatu tindak pidana. ${ }^{36}$

Kemudian, bagian dari unsur subjektif berikutnya adalah keadaan-keadaan (circumstances), yakni keadaan yang mempengaruhi pada saat perbuatan itu dilakukan dan/atau saat setelah perbuatan dilakukan. Terakhir adalah adanya sifat melawan hukum, yakni apabila perbuatan itu bertentangan dengan hukum yang berkenaan dengan suatu larangan atau perintah dan adanya sifat dapat dihukum, yakni berkenaan dengan alasan-alasan yang membebaskan si pelaku dari hukuman. ${ }^{37}$

Pasal 18 UUPK membuat sejumlah larangan penggunaan klausula baku dalam standar kontrak, yaitu sebagai berikut: ${ }^{38}$

(1) Pelaku usaha dalam menawarkan barang dan/atau jasa yang ditujukan untuk diperdagangkan dilarang membuat atau mencantumkan klausula baku pada setiap dokumen dan/atau perjanjian apabila:

1. menyatakan pengalihan tanggung jawab pelaku usaha;

2. menyatakan bahwa pelaku usaha berhak menolak penyerahan kembali barang yang dibeli konsumen;

3. menyatakan bahwa pelaku usaha berhak menolak penyerahan kembali uang yang dibayarkan atas barang dan/atau jasa yang dibeli oleh konsumen;

36 lbid.

37 lbid.

38 Undang-Undang Nomor 8 Tahun 1999 tentang Perlindungan Konsumen, Pasal 18 ayat (I) dan (2). 
4. menyatakan pemberian kuasa dari konsumen kepada pelaku usaha baik secara langsung maupun tidak langsung untuk melakukan segala tindakan sepihak yang berkaitan dengan barang yang dibeli oleh konsumen secara angsuran;

5. mengatur perihal pembuktian atas hilangnya kegunaan barang atau pemanfaatan jasa yang dibeli oleh konsumen;

6. memberi hak kepada pelaku usaha untuk mengurangi manfaat jasa atau mengurangi harta kekayaan konsumen yang menjadi obyek jual beli jasa;

7. menyatakan tunduknya konsumen kepada peraturan yang berupa aturan baru, tambahan, lanjutan dan/atau pengubahan lanjutan yang dibuat sepihak oleh pelaku usaha dalam masa konsumen memanfaatkan jasa yang dibelinya;

8. menyatakan bahwa konsumen memberi kuasa kepada pelaku usaha untuk pembebanan hak tanggungan, hak gadai, atau hak jaminan terhadap barang yang dibeli oleh konsumen secara angsuran.

(2) Pelaku usaha dilarang mencantumkan klausula baku yang letak atau bentuknya sulit terlihat atau tidak dapat dibaca secara jelas, atau yang pengungkapannya sulit dimengerti.

(3) Setiap klausula baku yang telah ditetapkan oleh pelaku usaha pada dokumen atau perjanjian yang memenuhi ketentuan sebagaimana dimaksud pada ayat (1) dan (2) dinyatakan batal demi hukum.

(4) Pelaku usaha wajib menyesuaikan klausula baku yang bertentangan dengan undang-undang ini.

Klausula baku yang tercantum pada karcis kendaraan bermotor telah melanggar ketentuan dalam Pasal 18 ayat (1) huruf a, yakni "pelaku usaha dalam menawarkan barang 
dan/atau jasa yang ditujukan untuk diperdagangkan dilarang membuat atau mencantumkan klausula baku pada setiap dokumen dan/atau perjanjian apabila menyatakan pengalihan tanggung jawab pelaku usaha." Pencantuman klausula baku sebagaimana ketentuan di atas dapat dikategorikan sebagai tindak pidana. Hal ini sebagaimana ketentuan dalam Pasal 62 ayat (1): 39

Pelaku usaha yang melanggar ketentuan sebagaimana dimaksud dalam Pasal 8, Pasal 9, Pasal 10, Pasal 13 ayat (2), Pasal 15, Pasal 17 ayat (1) huruf a, huruf b, huruf c, huruf e, ayat (2), dan Pasal 18 dipidana dengan pidana penjara paling lama 5 (lima) tahun atau pidana denda paling banyak Rp. 2.000.000.000,00 (dua miliar rupiah).

Perumusan delik pencantuman klausula baku pada karcis kendaraan bermotor adalah sebagai berikut: (a) pelaku usaha; (b) menawarkan barang dan/atau jasa yang ditujukan untuk diperdagangkan; (c) membuat atau mencantumkan klausula baku pada setiap dokumen dan/atau perjanjian; dan (d) menyatakan pengalihan tanggung jawab pelaku usaha.

\section{Sanksi Tindak Pidana Pencantuman Klausula Baku pada Karcis Kendaraan Bermotor Menurut Undang-Undang Nomor 8 Tahun 1999 tentang Perlindungan Konsumen}

Di Indonesia, dalam praktiknya, klausula baku merupakan perjanjian yang prosedur pembuatannya bersifat sepihak. Hal ini berdasarkan Pasal 1 angka 10 UUPK yang mendefinisikan bahwa klausula baku adalah "setiap aturan atau ketentuan dan syaratsyarat yang telah dipersiapkan dan ditetapkan terlebih dahulu secara sepihak oleh pelaku usaha yang dituangkan dalam suatu dokumen dan/atau perjanjian yang mengikat dan wajib dipenuhi oleh konsumen." 40

\footnotetext{
${ }^{39}$ Undang-Undang Nomor 8 Tahun 1999 tentang Perlindungan Konsumen, Pasal 62 ayat (I).

40 Undang-Undang Nomor 8 Tahun 1999 tentang Perlindungan Konsumen, Pasal I angka I0.
} 
Sutan Remi Sjahdeini mengartikan, bahwa perjanjian baku merupakan perjanjian yang hampir seluruh klausul-klausulnya dibakukan oleh pemakainya. Dengan demikian, pihak yang lain pada dasarnya tidak mempunyai peluang untuk merundingkan atau meminta perubahan. Sjahdeini menekankan, yang dibakukan itu bukan formulir perjanjian tersebut, melainkan klausulklausulnya. ${ }^{41}$

Pencantuman klausula baku pada karcis parkir kendaraan bermotor di mall di Surabaya masih tumbuh subur. Fenomena ini lantas menjadi lazim dan menjadi hal yang tampak umum. Padahal, menurut Pasal 62 ayat (1) UUPK, pencantuman klausula baku termasuk perbuatan yang dapat diancam dengan pidana penjara paling lama 5 (lima) tahun atau pidana denda paling banyak Rp. 2.000.000.000,00 (dua miliar rupiah). ${ }^{42}$

Sebagaimana pengamatan yang terdokumentasikan oleh penulis, pencantuman klausula baku pada karcis parkir kendaraan bermotor benar-benar masih terjadi. Salah satu redaksi klausula baku yang tercantum pada karcis parkir kendaraan bermotor sebagaimana terdokumentasikan oleh peneliti adalah sebagai berikut: "Segala kerusakan ataupun kehilangan dari (bagian dari) kendaraan menjadi tanggung jawab dari pengendara". (BG Junction, Surabaya Pusat).

Hukum pidana Indonesia memandang, bahwa pencantuman klausula baku merupakan perbuatan yang dapat dipidana karena telah teRp.enuhinya unsur-unsur perbuatan pidana. Pertama, unsur subjektif, yakni unsur yang berasal dari dalam diri pelaku yang meliputi perbuatan yang disengaja (dolus) atau karena kelalaian (culpa). Kedua, unsur objektif, yakni unsur yang berasal dari luar diri perilaku yang terdiri atas perbuatan manusia, akibat

\footnotetext{
4I Sutan Remy Sjahdeini, "Kebebasan Berkontrak dan Perlindungan yang Seimbang Bagi Para Pihak dalam Perjanjian Kredit Bank di Indonesia," dalam Celina Tri Siwi K. Hukum Perlindungan Konsumen, 138.

${ }^{42}$ Undang-Undang Nomor 8 Tahun 1999 tentang Perlindungan Konsumen, Pasal 62 ayat ( I).
}

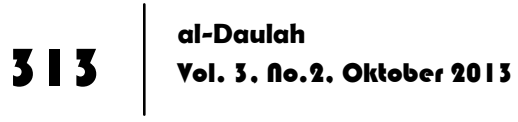


perbuatan manusia, keadaan-keadaan, adanya sifat melawan hukum, dan adanya sifat dapat dihukum..$^{43}$

Perumusan tindak pidana pencantuman klausula baku pada karcis kendaraan bermotor adalah sebagai berikut: (a) pelaku usaha; (b) menawarkan barang dan/atau jasa yang ditujukan untuk diperdagangkan; (c) membuat atau mencantumkan klausula baku pada setiap dokumen dan/atau perjanjian; dan (d) menyatakan pengalihan tanggung jawab pelaku usaha.

Hukum pidana pada umumnya mempunyai tiga teori yang mendasari diadakannya suatu hukuman. Pertama, teori imbalan (absolute), yakni dasar hukuman harus dicari dari kejahatan itu sendiri. Karena kejahatan itu telah menimbulkan penderitaan bagi orang lain, sebagai imbalannya si pelaku juga harus diberi penderitaan. Kedua, teori maksud (relative), yakni hukuman dijatuhkan untuk melaksanakan maksud dari hukuman itu untuk memperbaiki ketidakpuasan masyarakat sebagai akibat kejahatan itu. Ketiga, terori gabungan, yakni penjatuhan hukuman adalah untuk mempertahankan tata tertib hukum dalam masyarakat dan memperbaiki pribadi si penjahat. ${ }^{44}$

Pencantuman klausula baku merupakan salah satu wujud ketidakseimbangan dalam hal kedudukan antara konsumen dan pelaku usaha berdasarkan prinsip kebebasan berkontrak yang dapat dimanfaatkan oleh pelaku usaha untuk memperoleh keuntungan dengan jalan melanggar hukum. ${ }^{45}$

Pasal 62 ayat (1) UUPK telah mengatur sedemikian rupa, bahwa perbuatan produsen atau pelaku usaha yang tetap mencantumkan klausula baku dalam bentuk pengalihan tanggung jawab dapat dipidana. ${ }^{46}$

Pelaku usaha yang melanggar ketentuan sebagaimana dimaksud dalam Pasal 8, Pasal 9, Pasal 10, Pasal 13 ayat (2),

\footnotetext{
${ }^{43}$ Leden MaRp.aung, Asas-Teori-Praktik Hukum Pidana, 9-10.

${ }^{44}$ Ibid, I05- 07.

${ }^{45}$ Janus Sidabalok, Hukum Perlindungan Konsumen di Indonesia, 27.

${ }^{46}$ Undang-Undang Nomor 8 Tahun 1999 tentang Perlindungan Konsumen, Pasal 62 ayat ( I).
} 
Pasal 15, Pasal 17 ayat (1) huruf a, huruf b, huruf c, huruf e, ayat (2), dan Pasal 18 dipidana dengan pidana penjara paling lama 5 (lima) tahun atau pidana denda paling banyak Rp. 2.000.000.000,00 (dua miliar rupiah).

Secara teoritis, model pengaturan sanksi pidana pada ketentuan Pasal 62 ayat (1) UUPK di atas termasuk dalam stelsel alternatif, yaitu norma dalam UU ditandai dengan kata "atau". ${ }^{47}$ Dengan demikian, di sini sikap memilih pidana denda benar-benar atas pertimbangan Hakim secara cermat dan objektif serta praktis daripada pidana penjara atau karena memperhitungkan untung rugi pidana denda dibandingkan dengan pidana penjara. ${ }^{48}$

\section{Tinjauan Hukum Pidana Islam terhadap Sanksi Tindak Pidana Pencantuman Klausula Baku}

Hukum pidana Islam memandang, bahwa suatu perbuatan bisa dikatakan sebagai tindak pidana (jarimah) bila memang memenuhi unsur-unsur yang telah melekat pada istilah jarimah itu sendiri. Dalam hukum pidana Islam, unsur-unsur jarimah terbagi menjadi dua, yakni unsur umum dan unsur khusus. Unsur-unsur umum pada jarimah adalah sebagai berikut:

a. Adanya nas yang melarang perbuatan-perbuatan tertentu yang disertai ancaman hukuman atas perbuatan-perbuatan tersebut (al-rukn al-syar'i). ${ }^{49}$ Dengan demikian, sudah teRp.enuhilah unsur yang pertama ini, bahwa pencantuman klausula baku pada karcis kendaraan bermotor merupakan perbuatan yang dilarang dan diancam pidana sebagaimana ketentuan dalam Pasal 18 ayat (1) jo. Pasal 62 ayat (1) UUPK;

\footnotetext{
47 Didik Endro Purwoleksono, "Pengaturan Sanksi Pidana dalam Ketentuan UU (Bagian III)", dalam http://gagasanhukum.wordpress.com/2008/I2/I5/pengaturan-sanksi-pidana-dalamketentuan-uu-bagian-iii/, diakses pada 27 Maret 2013.

${ }^{48}$ Niniek Suparni, Eksistensi Pidana Denda dalam Sistem Pidana dan Pemidanaan, Jakarta: Sinar Grafika, 1996), 50.

49 A Djazuli, Fiqh Jinayah (Upaya Menanggulangi Kejahatan Dalam Islam), (Jakarta: PT RajaGrafindo Persada, 2000), 3.
} 
b. Adanya unsur perbuatan yang membentuk jarimah, baik berupa melakukan perbuatan yang dilarang atau meninggalkan perbuatan yang diharuskan (al-rukn al-madi). ${ }^{50}$ Dengan demikian, juga sudah teRp.enuhilah unsur yang kedua ini, bahwa pelaku telah melakukan perbuatan yang dilarang dengan tetap mencantumkan klausula baku pada karcis kendaraan bermotor; dan

c. Pelaku kejahatan adalah mukallaf, sehingga mereka dapat dituntut atas kejahatan yang mereka lakukan (al-rukn aladabi). ${ }^{51}$ Demikian pula sudah teRp.enuhilah unsur yang ketiga ini, bahwa pelaku usaha (koRp.orasi) dapat dituntut atas perbuatan yang dinilai telah melanggar ketentuanketentuan pidana, dalam hal ini adalah ketentuan Pasal 62 ayat (1) UUPK.

Di samping unsur umum di atas, ada unsur khusus yang hanya berlaku di dalam satu jarimah dan tidak sama dengan unsur khusus jarimah lain. ${ }^{52}$ Dalam hal ini, unsur-unsur khusus tindak pidana pencantuman klausula baku pada karcis kendaraan bermotor adalah sebagai berikut: (a) pelaku usaha; (b) menawarkan barang dan/atau jasa yang ditujukan untuk diperdagangkan; (c) membuat atau mencantumkan klausula baku pada setiap dokumen dan/atau perjanjian; dan (d) menyatakan pengalihan tanggung jawab pelaku usaha.

Khusus dalam masalah jarimah, maka ada dua hal yang tidak dapat dipisahkan dan merupakan satu mata rantai yang tidak akan pernah teRp.utus, yaitu kejahatan dan hukuman..$^{53}$ Perintah dan larangan saja tidak akan berarti sama sekali dan tidak cukup mendorong seseorang untuk meninggalkan suatu perbuatan atau melaksanakannya, untuk itu diperlukan sanksi berupa hukuman

\footnotetext{
${ }^{50} \mathrm{lbid}$.

${ }^{51}$ Ibid.

${ }^{52}$ Ibid.

${ }^{53}$ Abdul Salam, "Fiqih Jinayat (Hukum Pidana Islam)", dalam Makhrus Munajat, Dekonstruksi Hukum Pidana Islam, (Yogyakarta: Logung Pustaka, 2004), 41.
} 
bagi siapa saja yang melanggarnya. ${ }^{54}$ Dengan demikian, hukuman adalah suatu penderitaan atau nestapa, atau akibat-akibat lain yang tidak menyenangkan yang diberikan dengan sengaja oleh badan yang berwenang kepada seseorang yang cakap menurut hukum yang telah melakukan perbuatan atau peristiwa pidana. ${ }^{55}$

Hukuman bagi pelaku pencantuman klausula baku pada karcis kendaraan bermotor diancam dengan pidana sebagaimana ketentuan dalam Pasal 62 ayat (1), yakni sebagai berikut: 56

Pelaku usaha yang melanggar ketentuan sebagaimana dimaksud dalam Pasal 8, Pasal 9, Pasal 10, Pasal 13 ayat (2), Pasal 15, Pasal 17 ayat (1) huruf a, huruf b, huruf c, huruf e, ayat (2), dan Pasal 18 dipidana dengan pidana penjara paling lama 5 (lima) tahun atau pidana denda paling banyak Rp. 2.000.000.000,00 (dua miliar rupiah).

Menurut hukum pidana Islam, jika hukuman itu diakui keberadaannya, maka konsekuensinya adalah penerapan atau pelaksanaannya harus memenuhi tiga syarat. Syarat-syarat tersebut adalah:

a. Hukum dianggap mempunyai dasar kepada sumber-sumber syara', seperti al-Qur'an, as-Sunnah, ijma', atau undangundang yang ditetapkan oleh lembaga yang berwenang (ulil amri) seperti dalam hukuman ta'zir. Dalam hal ini, sanksi tindak pidana pencantuman klausula baku pada karcis kendaraan bermotor merupakan undang-undang yang ditetapkan oleh ulil amri.

b. Hukum disyaratkan harus bersifat pribadi atau perorangan. Ini mengandung arti bahwa hukuman harus dijatuhkan kepada orang yang melakukan tindak pidana dan tidak mengenai orang lain yang tidak bersalah. Dalam hal ini, sanksi tindak pidana pencantuman klausula baku pada karcis

54 Abdurrahman al-Maliki, Nizam al-'Uqubat (Sistem Sanksi dalam Islam), terjemah oleh Syamsuddin Ramadlan, (Bogor: Pustaka Thariqul Izzah, 2002), 2.

${ }^{55}$ Ahmad Wardi Muslich, Pengantar dan Asas Hukum Pidana Islam: Fikih Jinayah, (Jakarta: Sinar Grafika, 2004), 137.

${ }^{56}$ Undang-Undang Nomor 8 Tahun 1999 tentang Perlindungan Konsumen, Pasal 62 ayat (I).

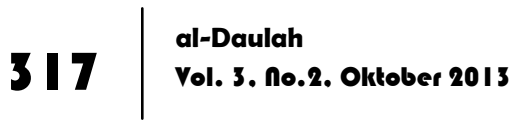


kendaraan bermotor memang diperuntukkan hanya kepada pelaku usaha yang melakukan perbuatan terlarang tersebut. c. Hukuman harus berlaku umum, yakni hukuman harus berlaku untuk semua orang tanpa adanya diskriminasi, apa pun pangkat, jabatan, status, dan kedudukannya.

Ditinjau dari segi macamnya jarimah yang diancamkan hukuman, hukuman dapat dibagi kepada tiga bagian, yaitu hukuman hudud, qisas-diyat, dan ta'zir. Dalam hal ini, sanksi tindak pidana pencantuman klausula baku pada karcis kendaraan bermotor termasuk dalam hukuman yang ditetapkan untuk jarimah ta'zir. Di mana memang tindak pidana yang dimaksud belum diatur di dalam nas, sehingga menjadi kewenangan ulil amri untuk menghukuminya.

Sebagaimana ketentuan pada Pasal 62 ayat (1) UUPK, bahwa pelaku tindak pidana diancam dengan pidana penjara paling lama 5 (lima) tahun. Dalam tinjauan hukum pidana Islam, pemenjaraan adalah menghalangi atau melarang seseorang untuk mengatur dirinya sendiri. Oleh karena itu, sanksi penjara harus bisa menjadi sanksi yang dapat mencegah. ${ }^{57}$ Kiranya itulah yang dimaksud oleh pembuat UU di Indonesia akan manfaat dari hukuman penjara tersebut.

Adanya pilihan terhadap sanksi (stelsel alternatif) sebagaimana Pasal 62 ayat (1) UUPK, yakni pidana penjara paling lama 5 (lima) tahun atau denda sebanyak-banyak Rp. 2.000.000.000,00 (dua miliar rupiah) diserahkan sepenuhnya kepada hakim untuk memutuskannya. Menurut tinjauan hukum pidana Islam, otoritas tersebut juga berada ditangan hakim. Karena tindak pidana tersebut merupakan kategori jarimah ta'zir, maka diserahkan kepada ulil amri sesuai dengan bidangnya, yakni badan yudikatif (hakim) yang bertugas sebagai penegak hukum. ${ }^{58}$

Pada kenyataannya, hukuman bagi jarimah ta'zir merupakan wewenang sepenuhnya bagi ulil amri. Dalam menjatuhkan

\footnotetext{
${ }^{57}$ Abdurrahman al-Maliki, Nizam al-'Uqubat (Sistem Sanksi dalam Islam), 257-258.

${ }^{58}$ Ahmad Wardi Muslich, Pengantar dan Asas Hukum Pidana Islam: Fikih Jinayah, 10.
} 
hukuman, ulil amri akan mempertimbangkan satu hal yang amat penting, yaitu kemaslahatan. Menurut Abdul al-Wahhab Khallaf, dalam proses penetapan hukum Islam yang tidak ditegaskan oleh teks syariah ( $\left.t a^{\prime} z i r\right)$, maslahat menjadi kerangka acuan, yang wujud nyatanya berupa potensi menolak keburukan atau kerusakan dan menghadirkan kebaikan atau kemanfataan. ${ }^{59}$

"Hukum ta'zir berlaku sesuai dengan tuntutan kemaslahatan."60

Tidak bisa dinafikan, bahwa tujuan diadakannya hukuman bagi pelaku tindak pidana pencantuman klausula baku pada karcis kendaraan bermotor telah memenuhi apa yang menjadi tujuan adanya hukuman dalam hukum pidana Islam. Pertama, menahan pembuat agar tidak mengulangi perbuatan jarimah-nya, atau agar ia tidak terus-menerus melakukan jarimah tersebut. Kedua, mendidik pelaku jarimah agar ia menjadi orang yang baik dan menyadari kesalahannya. Ketiga, di samping kebaikan pribadi pelaku, syariat Islam dalam menjatuhkan hukuman juga bertujuan membentuk masyarakat yang baik yang diliputi oleh rasa saling menghormati dan mencintai antara sesama anggotanya dengan mengetahui batas-batas hak dan kewajibannya.

Tujuan umum dari adanya hukum untuk memelihara dan mewujudkan kemaslahatan bagi kebutuhan-kebutuhan manusia, yakni kebutuhan akan agama, jiwa, akal, kehormatan, dan harta benda dapat terealisasikan dan mendapatkan jaminan. Di samping itu, upaya untuk menolak segala bentuk keburukan dan menghadirkan kemanfaatan semakin besar adanya dengan terwujudkannya suatu hukum yang mengandung asas kepastian, kemanfaatan, dan keadilan.

\footnotetext{
${ }^{59}$ Abdul al-Wahhab Khallaf, "Masadir al-Tasyri' al-Islamiy fi Ma La Nassa Fihi", dalam Asmawi, Teori Maslahat Dan Relevansinya Dengan Perundang-Undangan Pidana Khusus di Indonesia, (Jakarta: Badan Litbang dan Diklat Kementerian Agama RI, 20 I0), 43.

${ }^{60}$ Jaih Mubarok, Kaidah Fiqh Jinayah (Asas-Asas Hukum Pidana Islam), (Bandung: Pustaka Bani Quraisy, 2004), 49.
} 


\section{Penutup}

Pencantuman klausula baku pada karcis kendaraan bermotor oleh pengelola jasa parkir merupakan tindak pidana yang dapat diancam dengan sanksi sesuai dengan Pasal 18 ayat (1) huruf a jo. Pasal 62 ayat (1) Undang-Undang Nomor 8 Tahun 1999 Tentang Perlindungan Konsumen. Di mana sanksi tindak pidana tersebut adalah dengan pidana penjara paling lama 5 (lima) tahun atau pidana denda paling banyak Rp. 2.000.000.000,00 (dua miliar rupiah). Model pengaturan sanksi pidana tersebut termasuk dalam stelsel alternatif yaitu norma dalam UU ditandai dengan kata "atau". Dengan demikian, di sini sikap memilih pidana denda benar-benar atas pertimbangan hakim secara cermat dan objektif.

Sanksi tindak pidana pencantuman klausula baku pada karcis parkir kendaraan bermotor kepada pengelola jasa parkir dalam Pasal 62 ayat (1) UUPK menurut tinjauan hukum pidana Islam termasuk dalam sanksi yang ditetapkan untuk jarimah $t a^{\prime} z i r$, di mana tindak pidana yang dimaksud belum diatur di dalam nas, sehingga menjadi kewenangan ulil 'amri untuk menghukuminya.

\section{Daftar Pustaka}

Djazuli, A. Figh Jinayah (Upaya Menanggulangi Kejahatan Dalam Islam). Jakarta: PT RajaGrafindo Persada, 2000.

Farid, A Zainal Abidin. Hukum Pidana I. Jakarta: Sinar Grafika, 1995.

Hakim, Rahmat. Hukum Pidana Islam (Fiqih Jinayah). Bandung: Pustaka Setia, 2000.

Hamzah, Andi. Asas-Asas Hukum Pidana. Jakarta: Rineka Cipta, 2010.

-------. Hukum Pidana Ekonomi. Jakarta: Erlangga, 1996.

Hanafi, Ahmad. Asas-Asas Hukum Pidana Islam. Jakarta: Bulan Bintang, 1990.

Hukum Online, "Penindakan Pencantum Klausula Baku Terlarang Masih Minim," dalam 
http://www.hukumonline.com/berita/baca/hol17990/penindak an-pencantum-klausula-baku-terlarang-masih-minim,

Oktober 2012.

Khallaf, Abdul Wahhab. Kaidah Hukum Islam - terjemah oleh Faiz el-Muttaqin. Jakarta: Pusataka Amani, 2003.

Kitab Undang-Undang Hukum Pidana (KUHP) Indonesia.

Maliki (al-), Abdurrahman. Nidzam al-'Uqubat (Sistem Sanksi dalam Islam). terjemah oleh Syamsuddin Ramadlan, Bogor: Pustaka Thariqul Izzah, 2002.

Marpaung, Leden. Asas-Teori-Praktik Hukum Pidana. Jakarta: Sinar Grafika, 2008.

Moeljatno. Asas-Asas Hukum Pidana. Jakarta: Rineka Cipta, 2009.

Mubarok, Jaih. Kaidah Fiqh Jinayah (Asas-Asas Hukum Pidana Islam). Bandung: Pustaka Bani Quraisy, 2004.

Munajat, Makhrus. Dekonstruksi Hukum Pidana Islam. Yogyakarta: Logung Pustaka, 2004.

Muslich, Ahmad Wardi. Hukum Pidana Islam. Jakarta: Sinar Grafika, 2005.

-------. Pengantar dan Asas Hukum Pidana Islam. Jakarta: Sinar Grafika, 2004.

Prodjodikoro, Wirjono. Asas-Asas Hukum Pidana di Indonesia. Bandung: Refika Aditama, 2009.

Purwoleksono, Didik Endro. "Pengaturan Sanksi Pidana dalam Ketentuan UU (Bagian III)", dalam

http://gagasanhukum.wordpress.com/2008/12/15/pengaturansanksi-pidana-dalam-ketentuan-uu-bagian-iii/, 27 Maret 2013.

Rahayu, Karunia Asih, "Melawan Klausula Baku Tiket Parkir", dalam http://www.ylki.or.id/melawan-klausula-baku-tiketparkir.html, 11 Oktober 2012.

Sidabalok, Janus. Hukum Perlindungan Konsumen di Indonesia. Bandung: Citra Aditya Bakti, 2010.

Suparni, Niniek. Eksistensi Pidana Denda Dalam Sistem Pidana dan Pemidanaan. Jakarta: Sinar Grafika, 1996. 
Undang-Undang Nomor 8 Tahun 1999 Tentang Perlindungan Konsumen.

Wikipedia. "Daftar Pusat Perbelanjaan di Surabaya", dalam http://id.wikipedia.org/wiki/Daftar_Pusat_Perbelanjaan_di_S urabaya, 11 Oktober 2012.

Wikipedia. "Deskripsi Kota Surabaya", dalam http://id.wikipedia.org/wiki/Kota_Surabaya, 11 Oktober 2012. 